\title{
TWO CASES OF FREEMARTINISM IN SHEEP
}

\author{
I. SZATKOWSKA ${ }^{1}$. J. UDAŁA ${ }^{2}$. P. BARANOWSKI ${ }^{3}$, M. KATKIEWICZ ${ }^{\dagger}$. J. STEZPIEN ${ }^{5}$ \\ ${ }^{1}$ Department of Genetics and Animal Breeding. 'Department of Animal Reproduction, \\ ${ }^{3}$ Department of Cattle and Sheep Breeding. ${ }^{5}$ Department of Animal Anatomy. Agricultural University \\ of Szczecin. ${ }^{+}$Laboratory of Fur Animal Diseases. Warsaw Agricultural University. Poland
}

Received April 8, 1998

Accepted August 19, 1998

\begin{abstract}
Szatkowska I.. J. Udała. P. Baranowski. M. Katkiewicz. J. Stępień: Tro Cases of Freemciertinism in Sheep. Acta vet. Brno 1998. 67:189-192.

In the paper two cases of heavily masculinized individuals from heterosexual twin births are reported. They were found by cytogenetic analysis to be carriers of the lymphocyte XX/XY chimaerism while clinical examination showed testes situated in the rudimentary scrotum and significantly reduced male gamete transporting ducts. Analysis of histological preparations confirmed a considerable underdevelopment of gonads. epididymides and prostate gland. since these particular structures were present in the pelvic cavity of studied animals.
\end{abstract}

Infertility, twin sheep, chromosomal chimaerism $X X / X Y$

The extent of intersexuality in animals affected by the aforenamed developmental anomaly can vary greatly, from female reproductive organs only slightly reduced (S za tk ow ska et al. 1993) to male gonads situated in the rudimentary scrotum (Jonns on and Gustavsson 1969; Dain and Tucker 1970). In the relevant literature presenting studies on the extent of masculinization in freemartins one can find basically two standpoints referring to hermaphrodites. The first one, which supports the view of substantial masculinization of ewes including their external reproductive organs, is shared in the first place by authors describing occassional cases of hermaphrodites subsequently identified as freemartins owing to chromosomal studies. On the other hand. scientists reporting incidents of adult animals excluded from breeding due to their bareness are of the opinion that underdevelopment of the reproductive system only exceptionally refers to external genital organs ( $\mathrm{S} \mathrm{mith}$ et al. 1995). Thus, all contradictory statements covering the subject of masculinization of the ovine freemartins become clear. The aim of the present paper, in which two cases of heavily masculinized individuals are presented, is to contribute to this discussion.

\section{Materials and Methods}

Cytogenetic. morphological and histological studies were conducted on two ewes with disturbances in development of their external reproductive organs coming from heterosexual multiple births.

\section{Cytogenetic studies}

Blood samples for cytogenetic studies (identification of lymphocyte XX/XY chimaerism) were drawn from the external jugular vein of animals. Lymphocytes were cultured at $39.5^{\circ} \mathrm{C}$ for $72 \mathrm{~h}$ according to modified method of A rakaki and Sparkese (1963). Chromosome preparations were analysed conventionally based on the karyotype pattern for Ovis aries (ISCNDA). The ovine sex chromosome X is grouped to acrocentric chromosomes with a very short arm $p$ which makes it difficult to identify considering its great similarity with acrocentric autosomes.

\footnotetext{
Address for correspondence:

Dr. I. Szathouska

Dept. of Genetics and Animal Breeding

Agricultural Lniversity

ul. Dr. Judyma 6

$71-+6()$ Szczecin. Poland
}

Phone: $+48915+1521$

Fax: $+48915+1521$

E-mail: gen@ demeler.zoo.ar.szczecin.pl 
Chromosome Y. as the smallest metacentric in sheep karyotype. is easily identified. In view of the above. the arrangement of sex chromosomes in particular lymphocytes was initially determined by the absence or presence of chromosome Y. according to the method proposed by Dain (1971). Conventional chromosome analysis was subsequently supplemented with differential staining. receiving thus $\mathrm{C}$ bands. This method. based on $\mathrm{CBG}$ technique (Summer et al. 1971). enables complete identification of sex chromosomes considering the lack of $\mathrm{C}$ band on chromosome X.

\section{Histological studies}

Material for histological studies consisted of fragments of dissected reproductive organs fixed in a $4 \%$ buffered solution of formaldehyde. Paraffine sections. for review. Were stained with hematoxylin and eosin.

\section{Results and Discussion}

Cytogenetic studies confirmed in both cases the occurrence of 54.XX/54.XY cellular chimaerism, which was observed both in preparations stained with conventional Giemsa solution and in those stained with differential method. The percentage of particular lymphocyte lines within births, of which the studied animals came, is given below (Tab. 1).

Table 1

Cellular lines within multiple births connected by anastomoses in the embryonic life

\begin{tabular}{|c|c|cc|cc|}
\hline \multirow{2}{*}{ Ewe. No. } & \multirow{2}{*}{$\begin{array}{c}\text { Number of } \\
\text { metaphase plates }\end{array}$} & \multicolumn{2}{|c|}{ Number of cells } & \multicolumn{2}{c|}{ \% of cells } \\
& $54 . \mathrm{XX}$ & $54 . \mathrm{XY}$ & $54 . \mathrm{XX}$ & $54 . \mathrm{XY}$ \\
\hline 38920 & 94 & 28 & 66 & 29.8 & 70.2 \\
38930 & 82 & 24 & 61 & 25.7 & 74.3 \\
$\mathbf{2 8 8 3} \mathbf{0}$ & $\mathbf{8 5}$ & $\mathbf{1 7}$ & $\mathbf{6 8}$ & $\mathbf{2 0 . 0}$ & $\mathbf{8 0 . 0}$ \\
\hline 47690 & 90 & 16 & 74 & 17.8 & 82.2 \\
$\mathbf{b} / \mathbf{n}^{*} \mathbf{0}$ & $\mathbf{6 7}$ & $\mathbf{3 1}$ & $\mathbf{3 6}$ & $\mathbf{4 6 . 3}$ & $\mathbf{5 3 . 7}$ \\
\hline
\end{tabular}

* male lamb without number, culled

Clinical changes observed in the studied ovine freemartins are illustrated in Figures 1-5. The sex of specimen No. 3892 was difficult to define, although it should be classified as male based on testes present in this animal. On the posterior surface of the scrotum twin mammary glands were found with a pair of well developed teats. The penis (or enlarged clitoris) of this animal displayed a considerable malformation referring to its size and absence of the filiform appendage which is a characteristic of males. The urethral orifice occurred below the anus at the end of a mucous sulcus, slightly opened in the place where the vagina is usually found. Post mortem clinical examination revealed other changes connected with well-formed structures which develop from the Wolffian ducts during the foetal life. The testes, much smaller than in adult males, were equipped with male ejaculatory ducts, however, the rudimentary ductus deferens did not open at the seminal colliculus, usuallly observed in males, but into the pelvic cavity. The prostate gland as well as paired seminal vesicles were developed, the former being much smaller in size. On the other hand, the bulbo-urethral glands were not found, nor any other structures which could be identified with derivatives of the Müllerian ducts.

External reproductive organs of specimen No. 4769 were greatly similar. Both the urethral orifice and remarkably reduced gonads situated in the rudimentary scrotum confirmed this similarity. Clinical examination showed gonads of male character that opened blindly due to the absence of the ductus deferens. The prostate and bulbo-urethral glands were 
rudimentary. Structures which could be derived from the Müllerian ducts were not found in this individual, similarly to the one described above.

Histological analysis of gonads revealed well-marked changes of malformation in their microscopic structure in both cases. The seminiferous tubules did not show ability to spermatogenesis (except for one tubule in Plate XXX., Fig. 3 with visible single spermatozoa), since they displayed necrobiosis of seminiferous epithelium. Inside the duct of the epididymis of specimen 4769 numerous spermatocytes were present as the result of abnormal spermatogenesis. Moreover, many damaged cilia were found on the surface of epithelium. Accessory sex glands, i. e. the prostate gland and paired seminal vesicles, show'ed a considerable degree of fibrosis of their connective tissue stroma. They were lined with high columnar epithelium and completely deprived of their secretion products. Plate IV., Figs 4, 5.

The above studies performed on two ovine freemartins, which was confirmed by cytogenetical analysis revealing the lymphocyte $\mathrm{XX} / \mathrm{XY}$ chimaerism, demonstrate that the extent of masculinization of females coming from heterosexual multiple births may be significant. In this context the moment of initiating interfoetal circulation during development of heterosexual multiple births is very important (Mellor 1969; Sys a et al. 1980). If anastomoses connect still free-floating blastocysts, which is rather unusual after all, the influence of the male member on the character of freemartin's gonads is significant. On the other hand, if anastomoses appear in the later phase of the foetal life, the suppressing influence of the male co-twin on the reproductive system of a female will be limited. This is explained by the fact that differentiation of the primordial gonad in a masculine direction takes place during very early foetal life in the presence of SRY gene, which is localized on chromosome Y ( McElreavey et al. 1993; Dubin and Ostrer 1994). If this stage is not accompanied by the presence of anastomoses, the female gonad develops in accordance with genetic sex. In the situation when embryos are connected by anastomoses, sex of the primordial female gonad may undergo transformation. In further developmental stages the formation of gamete transport system occurs, and this part of development is under control of hormonal substances secreted by foetal testes (this process is spontaneous in females). This is associated with susceptibility of tissues of the Wolffian ducts to the action of the steroids mentioned above, which takes place in the precisely defined moment of development as well (Mittwoch 1983; Attal 1969; Gupta et al. 1990; Tsuji et al. 1991). As both Wolffian and Müllerian ducts are present in the organism of developing animal, the hormones. more accurate anti-Müllerian hormone, testosterone and $5 \alpha$ dihydrotestosterone. penetrating from one foetus to another by anastomoses may be responsible for masculinization of the secondary sex characters in the freemartin syndrome (Jost et al. 1973: Habert and Brignaschi 1991). The above statement may explain the fact why no structures deriving from the Müllerian ducts were found in the cases described above. which is repeatedly reported in the literature (Jonsson and Gustavsson 1969; Dain and Tucker 1970).

Freemartinism as a biological phenomenon with its different forms is very difficult to interpret explicitly. Two cases of freemartins presented here, as well as hermaphrodite specimens with the $\mathrm{XX/XY}$ chimaerism described until now, greatly varied in their phenotype, from females being developed normally, though barren, to animals with advanced masculinization, thus being classified as males. Considering the great heterogeneity of its forms, it seems difficult to assume an unequivocal attitude in the discussion on freemartinism. 


\section{Dva případy freemartinismu u ovcí}

$\mathrm{V}$ této studii jsou popsány dva př́ipady těžce maskulinizovaných jedinců u heterosexuálních dvojčat ovcí. Pomocí cytogenetické analýzy byl zjištěn přenos lymfocytárního XX/XY chimérismu, zatímco klinické vyšetření zvirrat prokázalo výskyt varlat $\mathrm{v}$ rudimentárním skrotu a značně redukovaný samčích vývodních cest. Analýza histologických preparátů potvrdila značnou retardaci gonád. nadvarlete a prostaty, které byly přitomny $\mathrm{v}$ pánevní dutině postižených zvírat.

\section{References}

ALEXANDER. G.. WILLIA.MS. D. 1964: Ovine freemartins. Nature 201: 1296-1297

ARAKAKI. D. T.. SPARKES R. S. 1963: Microtechnique for culturing leucocytes from whole blood. Cytogenetics 2: $57-6()$

ATTAL. J. 1969: Levels of testosterone, androstenedione, estrone and estradiol-17 $\beta$ in the testes of fetal sheep. Endocrinology 85: 280-289

BRUERE A. N. 1968: A cytogenetical investigations of six intersex sheep shown to be freemartins. Res. Vet. Sci. 9: $170-180$

CRIBIL. E. P.. DURAND. V.. CHAFFAUX. St. 1990: Frequence du freemartinisme chez des agnelles booroola merinos d Arles. Rec. Med. Vet. 166: 919-922

DAIN. A. R. 1971: The incidence of freemartinism in sheep. J. Reprod. Fert. 24: $91-97$

DAIN. A. R.. TUCKER. E. M. 1970: Cytogenetic. anatomical and blood group studies of sheep twin chimaeras. Proc. Roy. Soc. Lond. 175: 183-200

DUBIN. R.. OSTER. H. 1994: SRY is a transcriptional activator. Mol. Endocrinol. 8: $1182-1192$

GILL. J. J. B.. DAVIES. D. A. R.1991: XX/XY chromosomal chimerism in infertile sheep of the Cambridge breed. Genet. Sel. Evol. 23: 126-130

GUPTA. C. 1990: Activation of phospholipases during masculine differentiation. Proc. Soc. exp. Biol. Med. 188: 489-496

HABERT. R.. BRIGNASCHI. P. 1991: Developmental changes in in vitro testosterone production by dispersed Leydig cells during fetal life in rats. Arch. Androl. 27: 65-71

ISCNDA 1990: International System of Cytogenetic Nomenclature of Domestic Animals. Cytogen. Cell Genet. 53: $65-79$

JONSSON. G.. GUSTAVSSON. I. 1969: Blood cell chimerism in one of three triplet lambs. J. Hered. 60: 175-180

JOST, A.. VIGIER. G., PREPIN, J.. PERCHELLET. J. P. 1973: Studies on sex differentiation in mammals. Rec. Prog. Hormone Res. 29: 1-41

LONG. S. E. 1980: Some pathological conditions of the reproductive tract of the ewe. Vet. Rec. 106: 175-176

McELREAVEY. K.. VILAIN. E.. ABBAS, N.. HERSCOVITZ. I.. FELLOUS. M. 1993: A regulatory cascade hypothesis for mammalian sex determinatin: SRY represses a negative regulator of male development. Proc. Natl. Sci USA. 90: 3368-3372

MELLOR. D. J. 1969: Vascular anastomosis and fusion of foetal mambranes in multiple pregnancy in sheep. Res. Vet. Sci. 10: 361-367.

MITTWOCH. U. 1983: Heterogametic sex chromosomes and the development of the dominant gonad in vertebrates. Am. Nat. 122: 159-180

SMITH. K. C.. LONG. S. E.. PARKINSON. T. J. 1995: Congenital abnormalities of the ovine paramesonephric ducts. Brit. Vet. J. 154: 443-452

SPEEDING. R. N.. DOBSON. H. 1989: Diagnosis of freemartinism in sheep. Vet. Rec. 123: 18-19

STONE. W. H.. FRIEDMAN. J.. FREGIN. A. 1964: Possible somatic cell mating in twin cattle with erythrocyte mosaicism. Genetics 51: 1036-1044

STORMIONT. C.. WEIR, W. C.. LANE. L. L. 1953: Erythrocyte mosaicism in a pair of sheep twins. Science 118: 695-696

SUMMER, A. T.. EVANS. H. J.. BUCKLAND R. A. 1971: New technique for distinguishing between human chromosomes. Nature 232: 31-32

SYSA. P. S., SŁAWOMIRSKI. J.. KUNSSKA. A. 1980: Cytogenetyczne badania nad frymartynizmem u byd3a. Medycyna Wet. 4: 225-228

SZATKOWSKA. I. 1995: Frequency of lymphocytic XX/XY chimerism in Leine sheep coming from heterosexual twin and multiple births. J. Appl. Genet. 36: 373-378

SZATKOWSKA. I.. UDAŁA. J.. CHOMICZEWSKA-MAZARAKI. A. 1993: Przypadek leukocytarnego chimeryzmu komórkowego u niepłodnej maciorki rasy merynos polski. Medycyna Wet. 12: 565-567

TSUJI. Mi.. SHIMA. H., CUNHA. G. R. 1991: In vitro androgen-induced grouth and morphogenesis of the Wolffian duct within urogenital ridge. Endocrin. 128: 1805-1811 
Plate III.

Szatkowska I. et al.: Two cases... pp. 189-192.

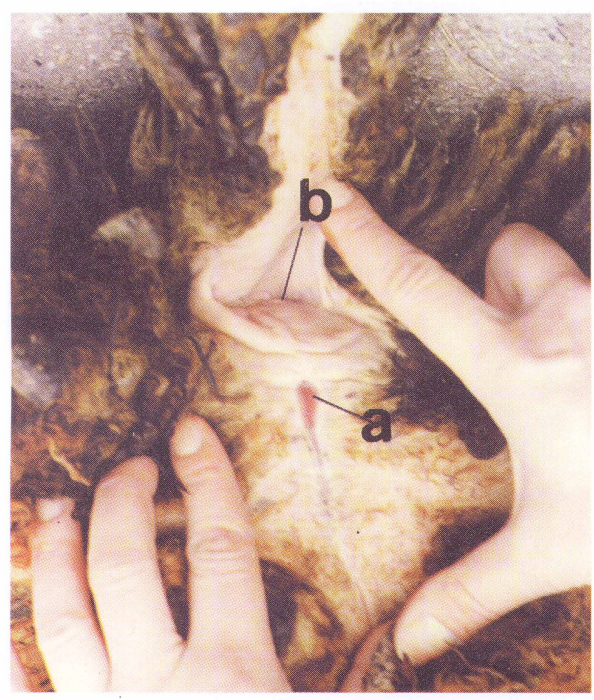

Fig. 1. Freemartin No. 4769; a - urethral orifice, $\mathrm{b}$ - anus.

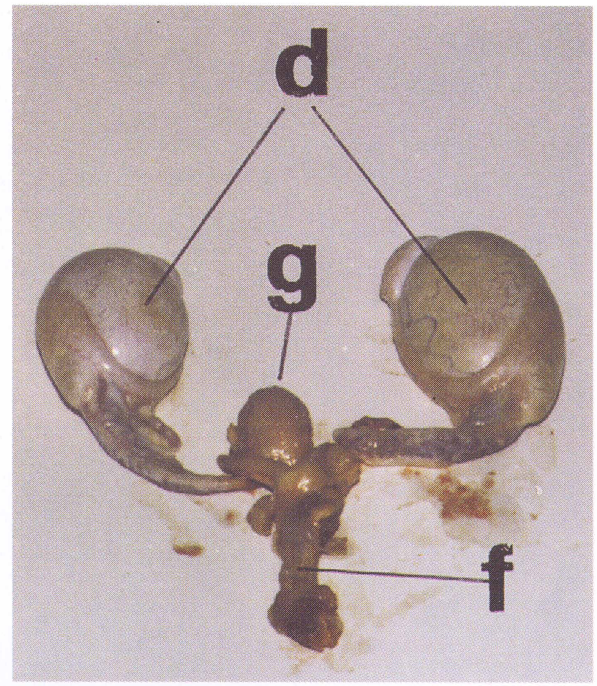

Fig. 2. Freemartin No. 4769; d - testes, f - prostate gland, $\mathrm{g}$ - urinary bladder.

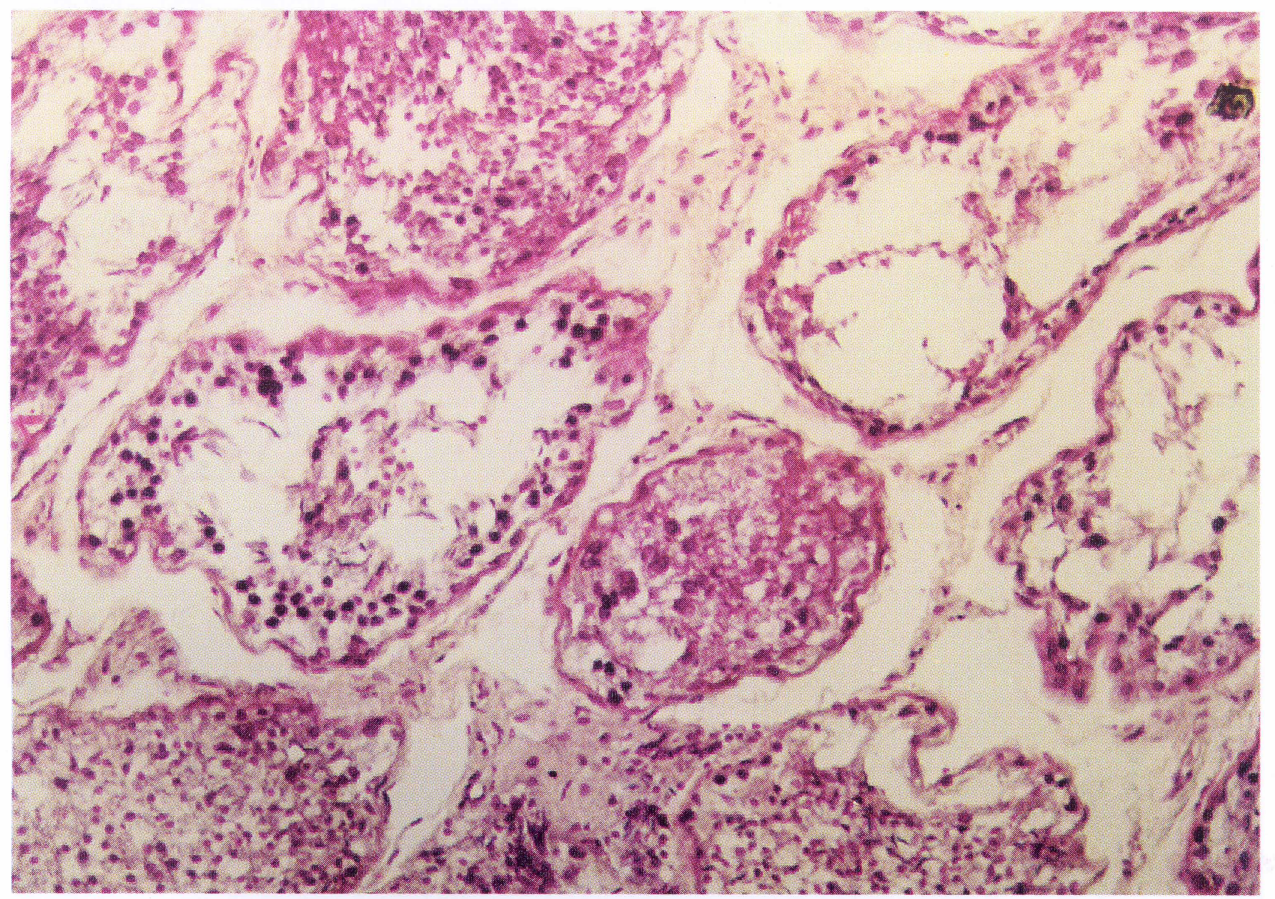

Fig. 3. Freemartin No. 4769; histological section of testes $(\times 400)$. 
Plate IV.

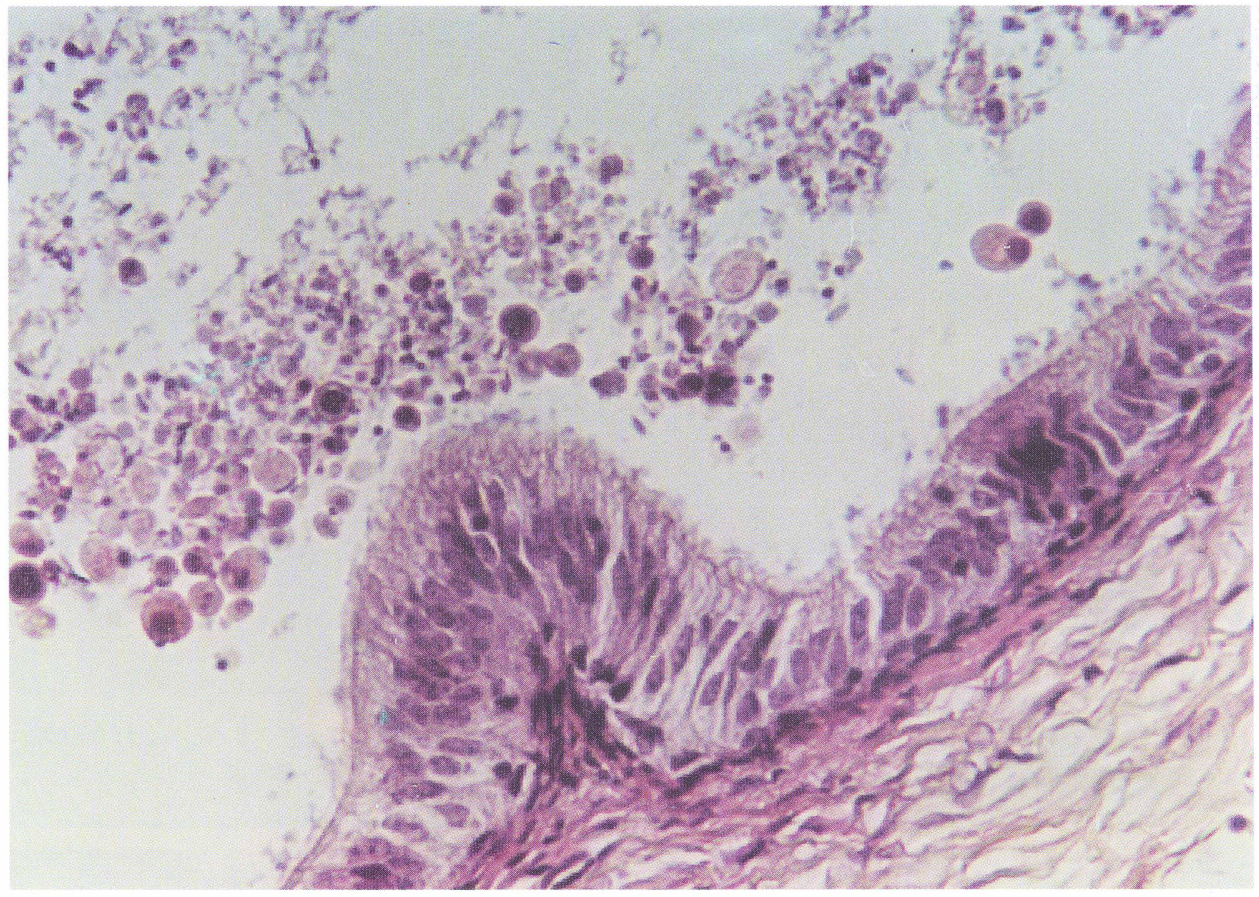

Fig. 4. Freemartin No. 4769; histological section of epididymis $(\times 400)$.

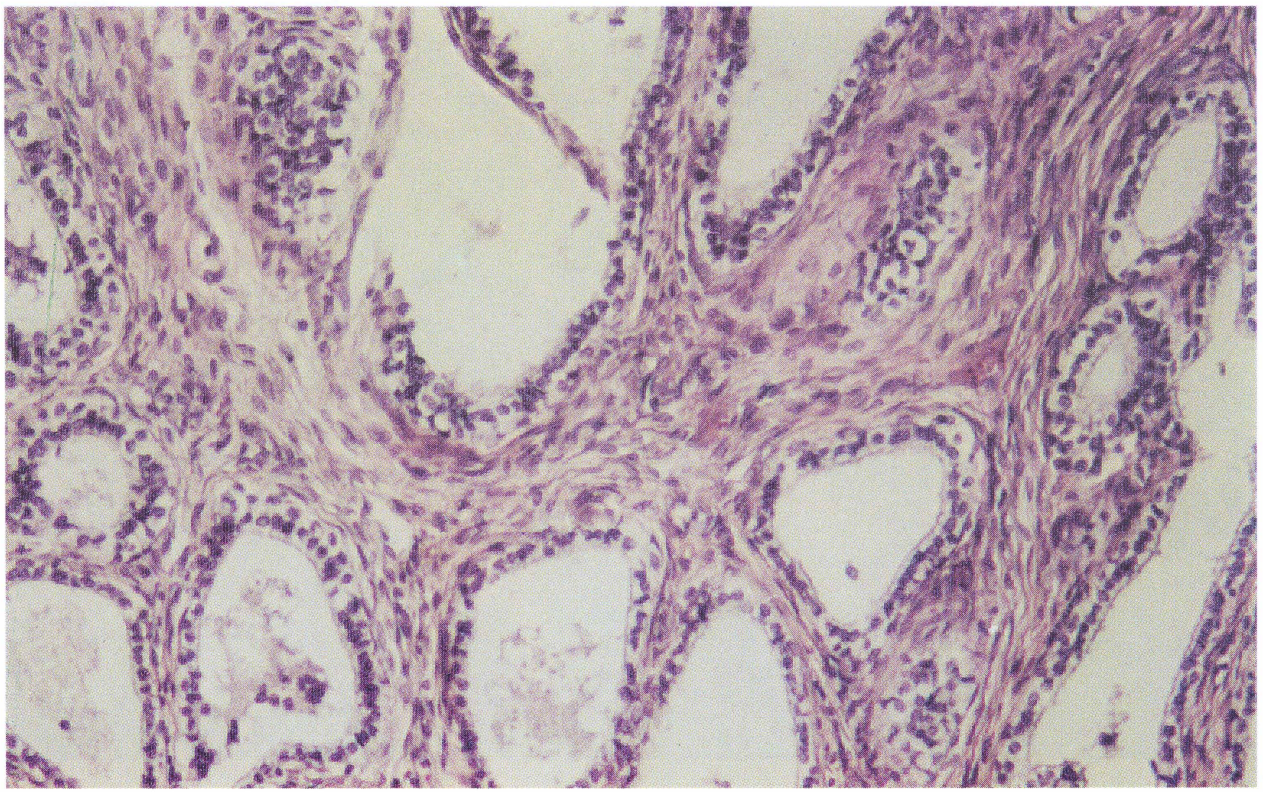

Fig. 5. Freemartin No. 4769; histological section of seminal vesicles $(\times 400)$. 